\begin{tabular}{|lcc|}
\hline & TOTOBUANG & \\
\hline Volume 7 & Nomor 1, Juni 2019 & Halaman 139—155 \\
\hline
\end{tabular}

\title{
KEEFEKTIFAN MODEL EXPERIENTIAL LEARNING DALAM PEMBELAJARAN MENULIS PUISI NARATIF SISWA KELAS VIII SMP NEGERI 2 DUA PITUE KABUPATEN SIDRAP
}

(The Effectiveness of The Experiential Learning Model in Writing Learning The Narrative Point of The VIII Class Student of The 2 Dua Pitue Kabupaten Sidrap)

\author{
A. Irmawati \\ Universitas Iqra Buru \\ Jln. Prof. Dr. A. Basalamah, S.E., M. Si. Namlea, Maluku \\ Pos-el: andiirmawati202@gmail.com \\ (Diterima: 30 November 2018; Direvisi: 19 Februari 2019; Disetujui: 9 Mei 2019)
}

\begin{abstract}
The Effectiveness of the Experiential Learning Model in Narrative Poetry Writing Learning in Second Pitue State Middle School 2 Sidrap Regency. This study aims to find out (1) the results of applying the model Experiential Learning in learning to write narrative poetry, (2) the results of application without using the model Experiential Learning in learning to write narrative poetry, (3) the effectiveness of the Experiential Learning model in writing narrative poetry of SMP Negeri 2 Dua Pitue, Sidrap Regency. The research design used is experimental. The population of this study was all eighth grade students of State Middle School 2 Dua Pitue Kabupaten Sidrap. The study sample consisted of two groups, namely grade students as a class experiment VIII. 2 and VIII.3 class as a class kontrol. Sampling in this study using purposive sampling, meaning that the determination of the sample is done intentionally with the amount determined in accordance with the needs of the analysis. The technique used to determine this research data is a written test. Data analysis techniques use descriptive statistical techniques and inferential statistics. The results showed that (1) the application of the model had a significant effect seen from the pretest to posttest, namely the average value of the pretest was 64 to 80.74 after the posttest, ie an average value of 16.74, (2) the results of the application without using the model Experiential Learning shows the results of the average value pretest of 61.63 and becomes 71.59 after the posttest with an increase of 9.96, (3) the test of data analysis using Independent Sample T-tes shows the acquisition of $p=0,000$ because $p \alpha \alpha=0.05$ in degrees of freedom 44, then $H$ which states the effectiveness of the application of models Experiential Learning in learning to write student narrative poetry is accepted. The results of this study conclude that the use of the Experiential Learning model is effective in learning to write narrative poetry in SMP Negeri 2 Dua Pitue, Sidrap Regency.
\end{abstract}

Keywords: Effectiveness, experiential learning model, poetry naratif

Keefektifan Model Experiential Learning dalam Pembelajaran Menulis Puisi Naratif SMP Negeri 2 Dua Pitue Kabupaten Sidrap. Penelitian ini bertujuan mengetahui (1) hasil penerapan model Experiential Learning dalam pembelajaran menulis puisi naratif, (2) hasil penerapan tanpa menggunakan model Experiential Learning dalam pembelajaran menulis puisi naratif, (3) keefektifan model Experiential Learning dalam menulis puisi naratif siswa kelas VIII SMP Negeri 2 Dua Pitue Kabupaten Sidrap. Desain penelitian yang digunakan bersifat eksperimen. Populasi penelitian ini adalah keseluruhan siswa kelas VIII SMP Negeri 2 Dua Pitue Kabupaten Sidrap. Sampel penelitian terdiri dari dua kelompok, yaitu siswa kelas VIII.2 sebagai kelas eksperimen dan kelas VIII.3 sebagai kelas control. Penarikan sampel dalam penelitian ini menggunakan purposive sampling, artinya penentuan sampel dilakukan secara sengaja dengan jumlah yang ditentukan sesuai dengan kebutuhan analisis. Teknik yang digunakan untuk menentukan data penelitian ini adalah tes tertulis. Teknik analisis data menggunakan teknik statistika deskriptif dan statistika inferensial. Hasil penelitian menunjukkan bahwa (1) penerapan model Experiential Learning berpengaruh signifikan dilihat dari nilai tes awal ke tes akhir yakni nilai rata-rata tes awal sebesar 64 menjadi 80,74 setelah dilakukan tes akhir, yakni nilai rata-rata sebesar 16,74, (2) hasil penerapan tanpa menggunakan model Experiential Learning menunjukkan hasil nilai rata-rata tes awal sebesar 61,63 dan menjadi 71,59 setelah dilakukan tes akhir dengan peningkatan sebesar 9,96, (3) uji analisis data dengan menggunakan Independent Sample T-tes menunjukkan perolehan nilai $p=0,000$ karena $p \leq \alpha=0,05$ pada derajat kebebasan 44, maka $H$ yang menyatakan keefektifan terhadap penerapan model Experiential Learning dalam pembelajaran menulis puisi naratif siswa diterima. Hasil 
penelitian ini menyimpulkan bahwa penggunaan model Experiential Learning efektif dalam pembelajaran menulis puisi naratif SMP Negeri 2 Dua Pitue Kabupaten Sidrap.

Kata-Kata Kunci: Keefektifan, model experiential learning, puisi

\section{PENDAHULUAN}

Keterampilan menulis merupakan salah satu proses perubahan bentuk pikiran atau angan-angan menjadi wujud lambing atau tanda tulisan yang bermakna baik tulisan bahasa maupun tujuan sastra. Pada aspek menulis bahasa ditekankan pada kegiatan menulis kebahasaan, seperti menulis paragraf. Pada aspek menulis sastra siswa diharapkan mampu mengapresiasi sastra yang diminati seperti puisi, prosa, dan drama. Puisi merupakan salah satu karya sastra yang diajarkan oleh guru Bahasa Indonesia di sekolah baik di tingkat Sekolah Dasar (SD), Sekolah Menengah Pertama (SMP), Sekolah Menengah Atas (SMA) maupun di Perguruan Tinggi (PT).

Kompetensi dasar menulis puisi memiliki dua tujuan utama. Pertama, siswa mampu menggunakan bahasa untuk memahami, untuk mengembangkan, dan mengomunikasikan, mengembangkan gagasan dan informasi, serta untuk berinteraksi dengan orang lain. Kedua, siswa diharapkan dapat memahami dan berpartisipasi dalam kegiatan menulis kreatif agar mereka dapat menghargai karya artistik budaya, intelektual, serta menerapkan nilainilai luhur untuk meningkatkan kematangan pribadi menuju masyarakat beradab (Depdiknas,2006:15).

Salah satu yang mendukung kreativitas dalam pengembangan kreativitas yaitu bekal pengalaman. Pengalaman adalah sesuatu yang pernah dirasakan, disaksikan, atau diperoleh tentang sesuatu kejadian dan memberikan efek bagi seseorang yang mengalami. Pengalaman sangat memegang peranan dalam mengembangkan kreativitas menulis ke arah yang lebih baik. Melalui pembelajaran pengalaman siswa akan menjalani kegiatan dengan tugas mereka sendiri. Terkait dengan pembelajaran menulis puisi siswa akan disibukkan oleh tugas-tugas secara alami mengantarkan mereka untuk menemukan ide atau gagasan baik melalui pengalaman emosional yang diperolehnya.

Berdasarkan uraian tersebut tampak bahwa pembelajaran menulis puisi sangat penting untuk diteliti. Pembelajaran menulis puisi bagi siswa SMP merupakan salah satu kompetensi yang harus dikuasai sehingga pembelajaran tersebut perlu mendapatkan perhatian yang serius. Namun, kenyataan menunjukkan bahwa pembelajaran menulis puisi di sekolah masih mengalami kendala yang disebabkan oleh penggunaan metode dan media yang digunakan dalam pembelajaran menulis puisi naratif kurang maksimal, sehingga kompetensi siswa juga kurang memadai. Hal tersebut juga dialami oleh siswa di SMP Negeri 2 Dua Pitue Kabupaten Sidrap.

Kondisi realitas yang diperoleh dari observasi awal peneliti terkait dengan kesulitan-kesulitan yang dialami oleh siswa kelas VIII. Ternyata ditemukan banyak siswa yang kesulitan mengungkapkan perasaan dalam bentuk puisi. Berbagai kesulitan yang dialami pada saat menulis puisi, baik dari unsur fisik dan unsur batin yang membangun sebuah puisi, maupun cara penggunaan diksi yang tepat. Hal ini disebabkan oleh model atau media pembelajaran yang digunakan guru masih monoton dan tidak membangkitkan kreativitas siswa. Selain itu, guru lebih mengarah pada teori-teori tentang puisi. Akibatnya, dapat memunculkan kejenuhan dan rasa bosan siswa, padahal yang terpenting adalah memadukan antara teori puisi dengan praktiknya/penciptaan puisi sehingga siswa dapat mengasah kreativitas dan inovatif yang dimilikinya.

Apabila mencermati kenyataan pembelajaran menulis puisi yang kurang memenuhi harapan maka diperlukan upaya pengefektifan pembelajaran menulis puisi di kelas. Dalam hal ini, diperlukan suatu teknik yang dapat membantu siswa mengatasi permasalahan dalam menulis puisi, salah satu teknik yang diasumsikan untuk 
membantu siswa dalam mencipta sebuah karya sastra, khususnya mencipta puisi yaitu melalui model Experiential Learning Experiential Learning sebagai model yang memudahkan siswa untuk mengembangkan ide-ide ke dalam bentuk puisi karena terdapat pengalaman yang berkesan yang dialami siswa.

\section{LANDASAN TEORI}

\section{Pengertian Menulis}

Marwoto (1987:19) menjelaskan bahwa menulis adalah mengungkapkan ide atau gagasannya dalam bentuk karangan secara leluasa. Selanjutnya, Tarigan (2005:1) mengemukakan bahwa menulis adalah menurunkan atau melukiskan gambargambar grafis yang menghasilkan suatu bahasa yang dipahami oleh seseorang sehingga orang lain dapat membaca lambang-lambang grafis tersebut dan dapat memahami bahasa dan grafis itu. Sejalan dengan pendapat Suparno dan Yunus (2008:13) menulis merupakan suatu kegiatan penyampaian pesan (komunikasi) dengan menggunakan bahasa tulis sebagai alat atau medianya.

Berdasarkan pendapat para pakar di atas dan penjelasan tentang menulis maka Peneliti dapat menarik kesimpulan bahwa menulis adalah proses penyampaian pikiran, angan-angan, perasaan dalam bentuk lambang/tanda/tulisan yang bermakna.

\section{Pembelajaran Menulis Puisi}

Pembelajaran menulis puisi merupakan latihan mengarang singkat yang tidak terlalu sulit dikerjakan, asal guru tidak terlalu jauh mengharapkan bahwa semua siswa harus berhasil menjadi penyair. Pembelajaran menulis puisi sebagai salah satu pembelajaran menulis kreatif, tersurat pada salah satu butir pembelajaran yang berbunyi "menulis pengalaman pribadi yang paling menarik dalam bentuk puisi atau cerita pendek dan mendiskusikannya". Berdasarkan butir pembelajaran ini bahwa pengalaman merupakan sumber belajar yang dipakai sebagai bahan pembelajar. Kelas yang kaya bahasa dapat mempermudah mengembangkan daya imajinasi siswa.

Supaya pembelajaran lebih terarah dan efektif pelaksanaannya, guru sebaiknya berpedoman pada prinsip-prinsip pembelajaran. Pembelajaran bahasa dan sastra indonesia harus memperhatikan prinsip-prinsip, antara lain dari yang paling mudah ke yang sukar, dari hal-hal yang dekat ke yang jauh, dari yang sederhana ke yang rumit, dari yang diketahui ke yang belum diketahui, dan dari yang konkret ke yang abstrak. Sementara itu, Dixon dan Nessel (dalam Ahmadi, 1990:29) mengemukakan beberapa prinsip tentang pembelajaran menulis, termasuk menulis puisi yang akan efektif jika berpedoman pada prinsip-prinsip berikut 1) dalam kegiatan menulis, siswa harus menulis berdasarkan pada topik atau ide pribadi yang bermakna, 2) sebelum menulis, hendaknya guru memberikan percakapan, 3) menulis merupakan keterampilan yang mudah, 4) menulis hendaknya diberikan dalam bentuk komunikasi bukan dalam bentuk tugas latihan, 5) menghindari pengoreksian kesalahan ketatabahasaan dan unsur mekanik lainnya sebagai akibat keterbatasan siswa, dan 6) antara menulis dan membaca atau keterampilan berbahasa yang lain hendaknya ada hubungan yang jelas.

Perasaan dan pengalaman manusia selalu lebih luas dan tidak mungkin seluruhnya terungkap oleh bahasa. Oleh karena itu, puisi ditulis untuk menyapa perasaan bukan pikiran. Memaknainya pun bukan melalui terjemahan kata per kata, tetapi melalui pengerahan batiniah sehingga pembaca dibawa tenggelam dan hanyut ke dasar samudra pengalaman (Alwasilah, 2008).

\section{Langkah-langkah Menulis Puisi}

Ada empat tahap penciptaan puisi menurut Munandar dalam Pradopo, dkk (1998), yaitu:

1. Tahap persiapan dan usaha.

Makin banyak pengalaman atau
informasi yang dimiliki seseorang
mengenai masalah atau tema yang


digarapnya, makin memudahkan dan melancarkan pelibatan dirinya dalam proses tersebut (Munandar dalam Pradopo, 1998).

2. Tahap inkubasi atau pengendapan.

Setelah semua informasi dan pengalaman yang dibutuhkan serta berusaha dengan pelibatan diri sepenuhnya untuk menimbulkan ide-ide sebanyak mungkin, maka biasanya diperlukan waktu untuk mengendapkan semua gagasan tersebut, diinkubasi dalam alam prasadar, di sini semua "bahan mentah" diolah dan diperkaya dengan masukan dari alam prasadar, yaitu semua pengetahuan dan pengalaman relevan yang pernah diperoleh, tetapi tidak lagi secara sadar (Munandar, 1998).

3. Tahap iluminasi.

Dalam mengekspresikan ide atau gagasan puisi dibutuhkan keterampilan berbahasa karena bahasalah dipergunakan sebagai media ekspresi. Semakin sering menulis puisi, akan semakin terampil mengekspresikan puisi dalam bahasa indah yang estetis.

4. Tahap verifikasi

Ketika seorang penulis melakukan penilaian secara kritis terhadap karyanya sendiri. bila perlu, karya tersebut dapat dimodifikasi, ditambah, atau dihilangkan bagian-bagian yang tidak sesuai menurut perasaannya. Pada tahap ini pengarang akan mengambil jarak, melihat produknya seperti dengan mata orang lain, sehingga dapat memberikan tinjauan secara kritis (Munandar, 1998).

\section{Pengertian Puisi}

Puisi dapat didefinisikan sebagai jenis bahasa yang mengatakan lebih banyak dan lebih intensif daripada apa yang dikatakan oleh bahasa harian. (Perrine, 1974:553). Perbedaan antara puisi dengan novel, drama, atau cerita pendek terletak pada kepadatan komposisi dengan konvensi yang ketat, sehingga puisi tidak memberi ruang gerak kepada penyair dalam berkreasi secara bebas. Wajar jika puisi dikatakan sebagai the most condensed and concentrated form of literature (Perrine, 1974:559) yang maksudnya adalah puisi merupakan bentuk sastra yang paling padat dan terkonsentrasi.).

Puisi menurut Waluyo (1995:25) adalah bentuk karya sastra yang mengungkapkan pikiran dan perasaan penyair secara imajinatif dan disusun dengan pengonsentrasian struktur fisik atau struktur batin lainnya. Kamus Besar Bahasa Indonesia (2005:903) menguraikan pengertian puisi sebagai salah satu karya sastra yang terikat oleh irama, matra, rima, dan penyusunannya. Bentuk puisi ditata secara cermat, sehingga mempertajam kesadaran orang atau membangkitkan pengalaman pembacanya.

Menurut Hudson (dalam Aminuddin, 2009:134) mengungkapkan bahwa puisi merupakan salah satu kompetensi dalam pembelajaran sastra yang menggunakan kata-kata sebagai media penyampaiannya yang nantinya menghasilkan ilusi dan imajinasi. Suryaman (2010:8) juga memberikan definisinya terhadap puisi yaitu puisi sebagai karya emosi, imajinasi, pemikiran, ide, nada, irama, kesan panca indra, susunan kata, kata-kata kiasan, kepadatan, dan perasaan yang bercampurbaur dengan memperhatikan pembaca.

Pengertian lama puisi diungkapkan oleh Wirjosudarmo dalam Pradopo (2010: 309) mengemukakan bahwa puisi itu karangan yang terikat, terikat oleh, (1) banyak baris dalam setiap bait (kuplet/stofa, suku karangan), (2) banyak kata dalam setiap bait, (3) banyak suku kata dalam setiap baris, (4) rima, (5) irama. Sedangkan menurut pengertian baru, puisi didefinisikan sebagai karya sastra yang tidak lagi irama. Secara etimologi, istilah puisi berasal dari bahasa yunani poeima "membuat" atau poesis "pembuatan" dan dalam bahasa inggris disebut Poem atau Poetry sebagai istilah jenis puisi oleh karena itu, istilah puisi sebaiknya dipergunakan sebagai jenis sastra: poem. Dengan demikian, penggunaan istilah puisi dan sajak tidak kacau (Pradopo, 2012:307). 
Secara sederhana puisi adalah bentuk karya sastra yang menggunakan kata-kata indah dan kaya makna (Kosasih, 2012:97) sedangkan menurut pengertian baru, puisi didefinisikan sebagai karya sastra yang tidak lagi memedulikan ikatan-ikatan formal yang ada di dalamnya (Pradopo, 2013:312).

\section{Jenis-jenis Puisi}

Berikut ini adalah jenis-jenis puisi menurut Waluyo (1995:135), di antaranya:

a. Puisi naratif, lirik, dan deskriptif

Puisi naratif mengungkapkan cerita atau penjelasan penyair. Puisi-puisi naratif, misalnya epik, romansa, balada, dan syair (berisi cerita). Puisi lirik mengungkapkan aku lirik atau gagasan pribadinya. Jenis puisi lirik misalnya elegi, ode, dan serenada. Sedangkan puisi deskriptif penyair bertindak sebagai pemberi kesan terhadap keadaan atau peristiwa, benda, atau suasana yang dipandang menarik perhatian penyair. Jenis puisi deskriptif misalnya puisi satire, kritik sosial, dan puisi-puisi impresionistik.

\section{b. Puisi kamar dan puisi auditorium}

Puisi kamar adalah puisi yang cocok dibaca sendirian atau dengan satu atau dua pendengar saja di dalam kamar. Puisi auditorium adalah puisi yang cocok untuk dibaca di auditorium, di mimbar yang jumlah pendengarnya dapat ratusan orang.

\section{c. Puisi fisikal, platonik, dan metafisik}

Puisi fisikal bersifat realistis artinya menggambarkan kenyataan yang ada. Yang dilukiskan adalah kenyataan dan bukan gagasan. Hal-hal yang dilihat, didengar atau dirasakan merupakan objek ciptaannya. Puisi platonik adalah puisi yang sepenuhnya berisi hal-hal yang bersifat spiritual atau kejiwaan. Puisi metafisikal adalah puisi yang bersifat filosofis dan mengajak pembaca merenungkan kehidupan dan merenungkan tuhan.

\section{d. Puisi subjektif dan puisi objektif}

Puisi subjektif juga disebut puisi personal, yakni puisi yang mengungkapkan gagasan, pikiran, perasaan, dan suasana dalam diri penyair sendiri. Puisi objektif berarti puisi yang mengungkapkan hal-hal di luar diri penyair itu sendiri. Puisi objektif disebut juga puisi impersonal.

\section{e. Puisi konkret}

Puisi yang bersifat visual, yang dapat dihayati keindahan bentuk dari sudut penglihatan (Poems for the eye). Dalam puisi konkret ini, tanda baca dan huruf-huruf baik huruf besar maupun kecil berpotensi gambar.

\section{f. Puisi diafan, gelap, dan prismatis}

Puisi diafan atau puisi polos adalah puisi yang kurang sekali menggunakan pengimajian, kata konkret, dan bahasa figuratif, sehingga puisinya mirip dengan bahasa sehari-hari. Puisi gelap adalah puisi yang terlalu banyak menggunakan majas dan sukar untuk ditafsirkan. Sedangkan dalam puisi prismatis penyair mampu menyelaraskan kemampuan menciptakan majas, verifikasi, diksi dan pengimajian sedemikian rupa sehingga pembaca tidak terlalu mudah untuk menafsirkan maknanya namun tidak terlalu gelap.

\section{g. Puisi parnasian dan puisi inspiratif}

Parnasian adalah puisi yang diciptakan dengan pertimbangan ilmu atau pengetahuan dan bukan disadari oleh inspirasi karena adanya mood dalam jiwa penyair. Sedangkan puisi inspiratif diciptakan berdasarkan mood atau passion. Penyair benar-benar masuk ke dalam suasana yang hendak dilukiskan. Suasana batin penyair benar-benar terlibat ke dalam puisi.

\section{h. Stansa}

Stansa artinya puisi yang terdiri dari 8 baris. Stansa berbeda dengan oktaf karena oktaf dapat terdiri atas 16 atau 24 baris.

i. Puisi demonstrasi dan pamflet

Puisi demonstrasi adalah Puisi yang melukiskan perasaan kelompok bukan perasaan individu. Puisi demonstrasi sering 
menggunakan kata-kata yang membakar semangat. Puisi pamflet juga merupakan protes sosial. Disebut puisi pamflet karena bahasanya adalah bahasa pamflet. Katakatanya mengungkapkan rasa tidak puas kepada keadaan.

\section{j. Alegori}

Puisi yang dimaksudkan untuk memberikan nasihat tentang budi pekerti dan agama. Jenis alegori yang terkenal ialah parable yang juga disebut dongeng perumpamaan.

Berdasarkan jenis-jenis puisi tersebut, peneliti memilih jenis puisi naratif untuk diterapkan dalam pembelajaran menulis teks puisi di kelas karena dari segi isi puisi tersebut bisa membuat siswa mudah menuliskan puisi dengan mengungkapkan cerita.

Puisi naratif adalah puisi yang mengungkapkan cerita atau penjelasan penyair. Ada puisi naratif yang sederhana, sugestif, dan kompleks. Puisi-puisi naratif, misalnya epik, romansa, balada, dan syair (berisi cerita).

Puisi naratif ini juga tidak berbeda dengan prosa naratif bernada menceritakan, sehingga untaian puisi itu merupakan untaian cerita. Puisi tersebut mengandung sesuatu yang diceritakan. Sedangkan yang dijadikan objek cerita biasanya manusia sebagai tokoh. Oleh sebab itu, puisi naratif biasanya panjang.

\section{Contoh puisi naratif}

Jenazah (karya Mansur Samin)

berpagar beranda bunga

dan panji-panji Mahajaya

Malam makin tenang saja

di benakku suara: hingar sekretariat negara

sejenak tenang, langkah riuh berderap

silang siur dengan kapal terbang

gardu dan pagar-pagar besi gempar sekali

kegaduhan dan sepatu duri berlari

Kemudian mataku hinggap ke jenazah

dekat kesamaran gerombol mahasiswa

terpacak bendera

di ujung bangku tegak pekur para mahasiswa di lengannya pita hitam dan selampai dari celah-celah mereka, kulirik kertas putih tertulis nama : Arief Rahman Hakim

Malam tambah jauh dan makin tua tiba-tiba di belakangku muncul mahasiswa dengan ragu bertanya : "Bapak siapa?"

Wartawan atau alat negara?

Dengan sigap kujawab : "Saya penyair

yang turut ambil bagian

dalam demonstrasi tadi pagi!"

Dijalan pulang ke timur

desah gerimis mulai turun

aku tunduk melangkah dan melangkahp

lama baru sadar kemeja telah basah

Kutatap belakang jauhan tampak gedung-

gedung salemba

nun aula Universitas Indonesia

tempat upacara duka

terbaring putra tanah air

menanti kupahat dalam puisi

Mataku terkapar ke tengah pintu

dekat mimbar, sorot lampu

samping pilar dan aula yang tenang

di tengah terbaring jenazah

\section{Struktur Puisi}

Struktur puisi ada dua jenis, yakni struktur fisik dan struktur batin. Unsur fisik puisi dijabarkan sebagai berikut:

a. Diksi (pilihan kata)

Penyair sangat cermat dalam memilih kata-kata sebab kata-kata yang ditulis harus dipertimbangkan maknanya, komposisi bunyi dalam rima dan irama, kedudukan kata itu di tengah konteks kata lainnya dan kedudukan kata dalam keseluruhan puisi. Oleh sebab itu, di samping memilih kata yang tepat, penyair juga mempertimbangkan urutan katanya dan kekuatan kata-kata tersebut. Hendaknya disadari bahwa kata-kata dalam puisi bersifat konotatif artinya memiliki kemungkinan makna yang lebih dari satu. Menurut Emzir dan Rohman (2015:242), setiap kata yang digunakan dalam puisi akan mempunyai beberapa fungsi yaitu fungsi makna, bunyi, maupun bentuk. Ketepatan pemilihan kata tidak hanya sekadar bagaimana suatu makna bisa diungkapkan 
melainkan kata yang dipilih harus mengungkapkan satu ekspresi.

\section{b. Pengimajian}

Ada hubungan erat antara diksi, pengimajian, dan kata konkret. Diksi yang terpilih harus menghasilkan pengimajian yang dapat dihayati melalui penglihatan, pendengaran, atau cita rasa

Menurut Effendi (dalam Waluyo, 1995:80), pengimajian dalam puisi dapat dijelaskan sebagai usaha penyair untuk menciptakan atau menggugah timbulnya imaji dalam diri pembacanya, sehingga pembaca tergugah untuk menggunakan mata hati untuk melihat benda-benda, warna, dengan telinga hati mendengar bunyibunyian dan dengan perasaan hati kita menyentuh kesejukan dan keindahan benda dan warna.

\section{c. Kata konkret}

Kata konkret ialah kata-kata yang dapat dilukiskan dengan tepat, membayangkan dengan jitu akan apa yang hendak dikemukakan oleh penyair. Jika penyair mahir memperkonkret kata-kata, maka pembaca seolah-olah melihat, mendengar atau merasakan apa yang dilukiskan oleh penyair. Dengan demikian pembaca terlibat penuh secara batin ke dalam puisinya. Jika imaji pembaca merupakan akibat dari pengimajian yang diciptakan penyair, maka kata konkret ini merupakan syarat atau sebab terjadinya pengimajian itu. Dengan kata yang diperkonkret, pembaca dapat membayangkan secara jelas peristiwa atau kejadian yang dilukiskan oleh penyair.

\section{d. Bahasa figuratif (majas)}

Menurut Waluyo (1995:83), bahasa figuratif ialah bahasa yang digunakan penyair untuk menyatakan sesuatu dengan cara yang tidak biasa, yakni secara tidak langsung mengungkapkan makna. Pendapat lain dikemukakan oleh Pradopo (2010:62), adanya bahasa kiasan ini menyebabkan puisi menjadi menarik perhatian, menimbulkan kesegaran, hidup dan terutama menimbulkan kejelasan gambaran angan. Bahasa kiasan ini mengiaskan atau mempersamakan sesuatu hal dengan hal lain supaya gambaran menjadi jelas, lebih menarik dan hidup. Bahasa kiasan atau majas dibagi menjadi tujuh, yaitu perbandingan, metafora, perumpamaan epos, personifikasi, metonimi, sinekdoke, dan alegori.

\section{e. Versifikasi}

Dalam puisi terdapat bunyi yang disebut rima dan ritma. Rima adalah pengulangan bunyi di dalam baris atau larik puisi, pada akhir baris puisi atau pada keseluruhan baris atau bait puisi. Menurut Dola (2014:33), rima adalah pola bunyi yang terdapat dalam puisi. Menurut Emzir dan Rohman (2015:243), rima adalah bunyibunyi yang sama dan diulang baik dalam satuan kalimat maupun pada kalimat berikutnya. Menurutnya, rima dalam puisi dapat dibedakan menjadi tiga yaitu (1) asonansi atau keruntutan vokal yang ditandai oleh persamaan bunyi vokal pada satu kalimat seperti, rindu, sendu, dan mengharu, kalbu, (2) aliterasi atau persamaan bunyi konsonan pada kalimat atau antarkalimat dalam puisi, misalnya semua sepi sunyi sekali desir hari lari berenang, dan (3) rima akhir yaitu persamaan bunyi pada akhir baris pada puisi.

\section{f. Amanat}

Amanat adalah hal yang mendorong penyair untuk menciptakan puisinya. Amanat dapat ditemukan setelah mengetahui tema, perasaan, nada, dan suasana puisi. Amanat dimaknai sebagai nasihat yang ditangkap oleh pembaca setelah membaca puisi. Cara pembaca menyimpulkan amanat puisi sangat berkaitan dengan pandangan pembaca terhadap suatu hal.

\section{Model Pembelajaran Experiential Learning}

Model Experiential Learning adalah salah satu model pembelajaran yang berorientasi pada pengalaman peserta didik selama proses pembelajaran. Pengalaman yang dimaksud adalah serangkaian kegiatan 
yang dirancang guru untuk membantu siswa dalam mencari dan mengumpulkan pengetahuan baru. Untuk melibatkan siswa dalam pembelajaran, guru perlu menyediakan beragam pengalaman belajar.

Johnson dan Jonson (1998) dalam Arends (2004:10) bahkan memberikan penjelasan lebih mendetail, Experiential Learning disandarkan pada tiga asumsi, yakni pertama, kita belajar secara maksimal ketika kita terlibat secara pribadi (personal); kedua, pengetahuan haruslah ditemukan sendiri bila pengetahuan tersebut memang berarti bagi kita atau bisa membuat perbedaan dalam perilaku kita; dan ketiga, komitmen kita untuk belajar lebih tinggi ketika kita bebas menentukan sendiri tujuan belajar kita dan secara aktif berusaha mewujudkannya dalam batasan-batasan yang telah ditentukan. Pengalaman belajar menurut Yamin dan Ansari (2009:55-56) tergolong ke dalam tiga jenis pengalaman yang dijabarkan sebagai berikut:

\section{a. Pengalaman mental}

Pada pengalaman belajar melalui pengalaman mental siswa akan memperoleh informasi melalui media audiovisual. Beberapa pengalaman mental dapat diperoleh melalui membaca buku, mendengarkan ceramah, mendengarkan berita radio, melakukan perenungan, menonton televisi atau film.

\section{b. Pengalaman fisik}

Pengalaman belajar jenis ini meliputi kegiatan pengamatan, percobaan, penelitian, penyelesaian, kunjungan, karya wisata, pembuatan buku harian, dan beberapa bentuk kegiatan praktis lainnya. Lazimnya siswa dapat memanfaatkan seluruh inderanya ketika menggali informasi melalui pengalaman fisik.

\section{c. Pengalaman sosial}

Beberapa bentuk pengalaman sosial yang dapat dilakukan antara lain: melakukan wawancara dengan tokoh, bermain peran, diskusi, bekerja bakti, melakukan bazar, pameran, pengumpulan dana untuk bencana alam dan lain-lain.

\section{Kelebihan dan kelemahan model Experiential Learning}

Menurut Gani (2008:2003), apabila model Experiential Learning dilakukan dengan baik dan benar, maka ada beberapa keuntungan didapat antara lain:

a. Meningkatkan semangat dan gairah siswa;

b. Membantu tercapainya suasana yang kondusif;

c. Memunculkan kenyamanan dalam proses belajar;

d. Mendorong dan mengembangkan proses berfikir;

e. Mendorong siswa untuk dapat melihat dalam perspektif yang berbeda;

f. Memunculkan keadaan akan kebutuhan untuk berubah;

g. Memperkuat kesadaran diri;

Kelemahan model Experiential Learning adalah Subana (2011: 168) juga mengemukakan kelemahan dari model tersebut adalah walaupun model Experiential itu menarik karena mendorong dan melibatkan kegiatan belajar. Akan tetapi model tersebut tidak akan menguntungkan kalau tidak ditopang pemahaman (konseptualisasi) dari pengalaman itu.

\section{Langkah-langkah Pembelajaran Model Experiential Learning}

Adapun tahap-tahap pembelajaran dengan model Experiential Learning (Indriana, 2011:92) adalah sebagai berikut.

a. Pengalaman konkret

Pembelajaran diawali dengan memberikan aktivitas yang mampu menciptakan sebuah atmosfer, dan kerangka kerja yang kondusif. Pada tahap ini, siswa secara terbimbing mengikuti instruksi dari guru, dan belum memahami secara utuh mengenai kegiatan yang dilakukan. Tujuan utama pada tahap ini adalah untuk memberikan pengalaman konkret kepada siswa. 


\section{b. Observasi reflektif}

Pada tahap ini, siswa secara aktif mencari tahu tentang maksud dan tujuan dari kegiatan atau peristiwa yang dialaminya. Siswa cenderung akan mengumpulkan informasi dan menggunakan imajinasi untuk memecahkan masalah. Tahapan ini memungkinkan siswa untuk lebih baik dalam melihat berbagai situasi konkret dengan beberapa sudut pandang yang berbeda.

\section{c. Konseptualisasi abstrak}

Pada tahap ini siswa mulai mengumpulkan ide-ide kreatif berdasarkan dua tahap pembelajaran sebelumnya. Ide-ide tersebut disatukan menjadi sebuah konsep atau abstraksi selanjutnya akan dikembangkan menjadi sebuah produk atau inovasi baru.

\section{d. Eksperimentasi aktif}

Menurut Hamalik (2001) dalam Edu (2012) mengungkapkan langkah-langkah yang harus diperhatikan dalam pembelajaran menulis dengan menggunakan model Experiential Learning.

1) guru merumuskan secara saksama suatu rencana pengalaman belajar yang bersifat terbuka (open minded).

2) guru memberikan rangsangan dan motivasi pengenalan terhadap pengalaman.

3) siswa bekerja secara individual atau bekerja dalam kelompok-kelompok kecil/keseluruhan kelompok di dalam belajar berdasarkan pengalaman.

4) siswa ditempatkan pada situasi-situasi nyata, maksudnya siswa mampu memecahkan masalah dan bukan dalam situasi pengganti.

5) siswa aktif berpartisipasi di dalam pengalaman yang tersedia, membuat keputusan tersendiri, menerima konsekuensi berdasarkan keputusan tersebut.

6) menyajikan pengalaman yang telah dituangkan ke dalam bentuk tulisan, sehubungan dengan mata pelajaran untuk memperluas pengalaman belajar dan pemahaman siswa dalam melaksanakan pertemuan, yang nantinya akan membahas bermacam-macam pengalaman tersebut.

\section{Penerapan Pembelajaran Model Experiential Learning dalam Menulis Puisi}

Adapun penerapan pembelajaran model Experiential Learning dalam menulis puisi naratif, yaitu:

a) Pengalaman konkret

Pada tahap ini, guru memulai pelajaran dengan apersepsi, membekali pemahaman siswa tentang menulis puisi naratif. Siswa secara terbimbing mengikuti instruksi dari guru.

b) Observasi reflekstif

Pada tahap ini, siswa secara aktif mencari tahu tentang maksud dan tujuan dari kegiatan atau peristiwa yang dialaminya. Siswa akan mengumpulkan informasi dan menggunakan imajinasi mereka dalam mengingat pengalaman yang akan dituliskan ke dalam bentuk puisi naratif.

c) Konseptualisasi abstrak

Pada tahap ini, siswa mulai mengumpulkan ide-ide kreatif berdasarkan pengalaman dan imajinasi. Ide-ide tersebut disatukan menjadi sebuah konsep puisi naratif.

d) Eksperimentasi aktif

Pada tahap ini, siswa mulai menuangkan idenya menjadi sebuah produk yaitu puisi naratif sesuai dengan konsep yang telah disusun sebelumnya.

\section{Kriteria Penilaian}

Penentuan aspek yang dinilai dalam puisi berdasarkan tentang struktur fisik dan batin yang dikemukakan oleh Nurgiyantoro (2008 dalam Waluyo, 1995:29). 
Tabel 1

Aspek yang Dinilai

\begin{tabular}{|c|c|c|c|}
\hline $\mathrm{No}$ & Aspek & Kriteria & Skor \\
\hline 1. & Tema & $\begin{array}{l}\text { a. Dinyatakan dengan tepat. } \\
\text { b. Tepat, tetapi perlambanganya kurang tepat. } \\
\text { c. Kurang jelas tetapi masih bisa dipahami. } \\
\text { d. Pengungkapan temanya tidak jelas. } \\
\text { e. Temanya tidak jelas dan menyimpang dari isi. }\end{array}$ & $\begin{array}{c}13-15 \\
10-12 \\
7-9 \\
4-6 \\
1-3\end{array}$ \\
\hline 2. & Amanat & $\begin{array}{ll}\text { a. } & \text { Diungkapkan secara jelas dan bisa dipahami. } \\
\text { b. } & \text { Baik tetapi terlalu bertele-tele. } \\
\text { c. Kurang jelas tetapi bisa dipahami. } \\
\text { d. Tidak jelas dan penyampainnya kacau. } \\
\text { e. Benar-benar tidak jelas sehingga tidak bisa dipahami. }\end{array}$ & $\begin{array}{l}13-15 \\
10-12 \\
7-9 \\
4-6 \\
1-3\end{array}$ \\
\hline 3. & Pengimajian & $\begin{array}{l}\text { a. Pengimajian tepat. } \\
\text { b. Imaji yang digunakan kurang. } \\
\text { c. Pengimajian kurang bermakna tetapi masih bisa dipahami. } \\
\text { d. Tidak ada usaha pengembungan daya khayal penulis sehingga } \\
\text { pengungkapannya tidak hidup. } \\
\text { e. Lama sekali tidak menggunakan imajinasi. }\end{array}$ & $\begin{array}{l}13-15 \\
10-12 \\
13-15 \\
7-9 \\
4-6 \\
1-3\end{array}$ \\
\hline 4. & Diksi & $\begin{array}{l}\text { a. Pemilihan dan penggunaan kata sangattepat. } \\
\text { b. Sedikit sekali melakukan kesalahan dalam memilih dan } \\
\text { menggunakan kata. } \\
\text { c. Sering menggunakan kata yang kurang tepat. } \\
\text { d. Salah menggunakan kata dan sangat sukar menggunakan kata } \\
\text { secara tepat. } \\
\text { e. Kata-kata yang digunakan tidak terpilih sehingga makna yang } \\
\text { diungkapkan tidak bisa dipahami. }\end{array}$ & $\begin{array}{l}13-15 \\
10-12 \\
7-9 \\
4-6 \\
1-3\end{array}$ \\
\hline 5. & Kata konkret & $\begin{array}{l}\text { Menggambarkan suatu kiasan keadaan atau suasana batin sehingga } \\
\text { membangkitkan daya imaji pembaca. } \\
\text { b. Ada usaha penulis mengkonkretkan kata-kata sehingga dapat } \\
\text { menyaran kepada arti yang menyeluruh. } \\
\text { c. Ada usaha penulis mengkonkretkan kata-kata tetapi sedikit } \\
\text { menyaran kepada arti yang menyeluruh. } \\
\text { d. Ada usaha penulis mengkretkan kata-kata tetapi tidak menyaran } \\
\text { kepada arti yang tidak menyeluruh. } \\
\text { e. Tidak ada sama sekali usaha penulis mengonkretkan kata-kata, } \\
\text { sehingga tidak menyaran kepada arti yang menyeluruh. }\end{array}$ & $\begin{array}{l}10-12 \\
7-9 \\
4-6 \\
1-3\end{array}$ \\
\hline 6. & $\begin{array}{l}\text { Gaya } \\
\text { Bahasa }\end{array}$ & $\begin{array}{l}\text { a. Unsur tipografi dijalin sangat tepat. } \\
\text { b. Unsur tipogarafi kurang baik. } \\
\text { c. Penggunaan unsur tipogafi sudah ada, tetapi kadang-kadang } \\
\text { jalinanya tidak jelas. } \\
\text { d. Unsur tipografi masih lemah. } \\
\text { e. Penggunan unsur tipografi sama sekali belum dapat diwujudkan. } \\
\end{array}$ & $\begin{array}{c}13-15 \\
10-12 \\
7-9 \\
4-6 \\
1-3\end{array}$ \\
\hline 7. & Tipografi & 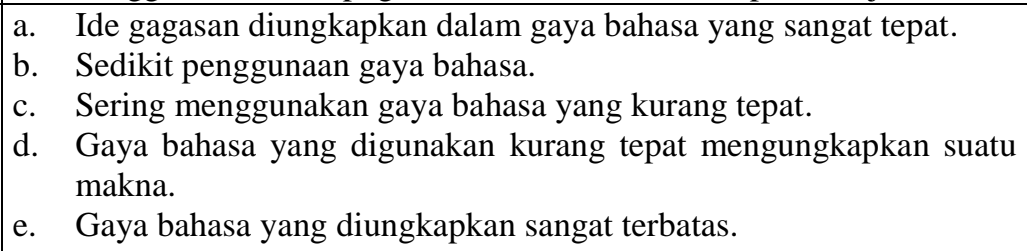 & $\begin{array}{l}13-15 \\
10-12 \\
7-9 \\
4-6 \\
1-3\end{array}$ \\
\hline
\end{tabular}

\section{METODE}

Penelitian ini menggunakan penelitian eksperimen. Penelitian eksperimen merupakan penelitian yang paling produktif, karena jika penelitian tersebut dilakukan dengan baik dapat menjawab hipotesis yang utamanya berkaitan dengan sebab-akibat.

Variabel penelitian terdiri atas dua, yaitu variabel bebas (independent variabel) yang dilambangkan $\mathrm{X}$ dan variabel terikat (dependent variabel) yang dilambangkan Y. 
a. Variabel bebas (X), metode pembelajaran yaitu menggunakan model Experiential Learning

b. Variabel terikat (Y), pembelajaran menulis puisi naratif siswa kelas VIII SMP Negeri 2 Pitue Kabupaten Sidrap.

Definisi operasional variabel dalam kajian ini adalah sebagai berikut.

1. Model Experiential Learning adalah suatu model proses belajar mengajar yang mengaktifkan pembelajar untuk membangun pengetahuan dan keterampilan melalui pengalamannya secara langsung.

2. Keefektifan adalah hasil yang lebih baik atau pengaruh positif dari perlakuan yang diberikan.

3. Kemampuan menulis puisi adalah kesanggupan menuangkan ide atau gagasan secara kreatif dan imajinatif dengan memperhatikan pilihan kata, rima, ritma, perasaan, nada, tema, dan amanat serta pemilihan kata-kata kias (imajinatif).

Penelitian ini menggunakan metode penelitian eksperimen. Desain penelitian yang digunakan adalah Nonequivalent Control Group Design. Desain penelitian tersebut didukung oleh populasi yang telah dipilih sebelumnya. Populasi adalah wilayah generalisasi yang terdiri atas objek/subjek yang mempunyai kualitas dan karakteristik tertentu yang ditetapkan oleh peneliti untuk dipelajari dan kemudian ditarik kesimpulannya. Adapun populasi dalam penelitian ini adalah siswa kelas VIII SMP Negeri 2 Dua Pitue Kabupaten Sidrap tahun ajaran 2015/2016. Siswa tersebut berjumlah 112 siswa dan tersebar dalam empat kelas.

Sampel adalah bagian dari jumlah dan karakteristik yang dimiliki oleh populasi. Sampel yang diambil dari populasi harus betul-betul mewakili (representatif) maka peneliti menggunakan teknik random sampling. Sampel dalam penelitian ini adalah kelas VIII.2 dan VIII.3 dengan jumlah siswa masing-masing 27 orang.

Instrumen yang dipakai dalam penelitian ini adalah tes menulis teks puisi naratif. Bentuk tes yang digunakan adalah tes menulis puisi naratif. Penilaian dilakukan terhadap hasil menulis puisi siswa. Dalam penelitian ini, hal yang diukur adalah keterampilan menulis puisi siswa yang berkaitan dengan pengajaran menulis puisi, maka data yang diteliti berupa hasil tes uraian menulis.

Observasi merupakan kegiatan dalam penelitian dengan melakukan kegiatan mengunjungi objek penelitian. Selanjutnya, perlu dilakukan adanya teknik tes dalam penelitian ini. Teknik yang digunakan untuk mengumpulkan data penelitian ini adalah teknik tes, maksudnya siswa ditugasi untuk menulis puisi berdasarkan pengalaman pribadi mereka.

Kegiatan awal dilakukan pada kedua kelas penelitian ini sebelum perlakuan (treatment) yaitu pemberian tes awal (pretest) kepada kelas eksperimen dan kelas kontrol tentang menulis puisi naratif. Selanjutnya, pemberian perlakuan dilakukan selama satu kali pertemuan. Peneliti memberikan penjelasan dari instruksi tentang pemanfaatan model Experiential Learning dalam pembelajaran menulis puisi. Langkah-langkah yang dilakukan adalah

a. Memperkenalkan model Experiential Learning.

b. Menerapkan metode Exeriential Learning dalam pembelajaran menulis puisi.

c. Setelah treatment, tindakan selanjutnya adalah pemberian tes menulis puisi untuk mengetahui kemampuan siswa setelah mendapatkan pembelajaran, baik pada kelas eksperimen maupun pada kelas kontrol, dan dilanjutkan dengan analisis hasil tes.

Adapun aspek penilaian puisi meliputi aspek tema, amanat, pengimajian, diksi, kata konkrit, tipografi, gaya bahasa dan nada. Rentang skor pembobotan pada setiap aspek yakni 1-15, hal itu berdasarkan kriteria penskoran pada aspek penilaian puisi naratif.

Analisis data yang telah dikumpulkan akan dianalisis menggunakan analisis statistik deskriptif yang bertujuan untuk mengetahui tingkat penguasaan materi 
melalui penggambaran karakteristik distribusi nilai pencapaian hasil belajar menulis puisi narasi dengan menerapkan model Experiential Learning dan pencapaian hasil belajar menulis puisi dengan menggunakan metode konvensional. Selain itu, teknik Analisis Statistika Inferensial juga digunakan untuk menganalisis data tersebut. Analisis statistika inferensial digunakan untuk menguji hipotesis penelitian dengan menggunakan uji-t. Namun, sebelum dilakukan pengujian hipotesis, terlebih dahulu dilakukan uji normalitas dan homogenitas.

\section{PEMBAHASAN}

1. Deskripsi Hasil Analisis Kemampuan Menulis Puisi Naratif dengan Menggunakan model Experiential Learning siswa kelas VIII SMP Negeri 2 Dua Pitue Kabupaten Sidrap

Deskripsi Hasil Analisis Deskriptif Data Tes Awal Kelas Kontrol. Berdasarkan hasil analisis data tes awal kelas kontrol dengan jumlah 27 siswa diperoleh gambaran yaitu tidak ada siswa yang memeroleh nilai 100 sebagai nilai maksimal.

a. Hasil Analisis Deskriptif pada Tes Awal Kelas Kontrol

Berdasarkan nilai tes awal kelas kontrol yang dinilai sesuai dengan tujuh kriteria penilaian penulisan puisi naratif, yaitu tema, amanat, pengimajian, diksi, kata konkret, tipografi, dan gaya bahasa. Hasil analisis penilaiannya yaitu, pada kelas kontrol siswa yang memperoleh nilai tertinggi 77 pada tahap tes awal. Pada kemampuan menulis puisi, nilai tersebut berada pada kategori baik. Judul puisi tersebut yaitu puncak. Pada aspek tema memperoleh nilai 13 karena tema dinyatakan dengan tepat. Pada aspek amanat memperoleh nilai 13 karena amanat yang diungkapkan tidak jelas. Pada aspek pengimajian memperoleh nilai 11 karena pengimajian kurang bermakna tetapi masih bisa dipahami. Pada aspek diksi memperoleh nilai 13 karena sedikit sekali melakukan kesalahan dalam memilih dan menggunakan kata. Pada aspek kata konkret memperoleh nilai 10 karena ada usaha penulis mengonkretkan kata-kata, tetapi sedikit menyaran pada arti yang menyeluruh. Pada aspek tipografi memperoleh nilai 9 karena unsur tipografi dijalin secara tepat. pada aspek gaya bahasa memperoleh nilai 9 karena ide diungkapkan dalam gaya bahasa yang sangat tepat. berdasarkan hasil analisis deskriptif tersebut diperoleh rangkuman nilai kemampuan menulis puisi naratif siswa kelas VIII SMP Negeri 2 Dua Pitue Kabupaten Sidrap.

\section{Tabel 2}

Kategori, Frekuensi, dan Persentase Tes Awal Kelas Kontrol

\begin{tabular}{|c|c|c|c|}
\hline Interval & Kategori & Frekuensi & Persentase \\
\hline $\begin{array}{c}86- \\
100\end{array}$ & $\begin{array}{c}\text { Sangat } \\
\text { Baik }\end{array}$ & 0 & 0 \\
\hline $76-85$ & Baik & 3 & 16.67 \\
\hline $56-75$ & cukup & 23 & 66.66 \\
\hline $10-55$ & Kurang & 1 & 16.67 \\
\hline & jumlah & 27 & 100 \\
\hline
\end{tabular}

b. Hasil Analisis Deskriptif pada Tes Akhir Kelas Kontrol

Berdasarkan hasil analisis data tes akhir kelas kontrol dengan 27 siswa yang dianalisis diperoleh hasil bahwa, yaitu tidak ada siswa yang mampu. memperoleh nilai 100 sebagai nilai maksimal. Nilai tertinggi yaitu 87 yang diperoleh 1 siswa dan nilai terendah yaitu 62 yang diperoleh 1 siswa.

c. Deskripsi Hasil Analisis Deskriptif Data Tes Aawal Kelas Eksperimen

Tes awal pada kelas eksperimen dinilai sesuai delapan kriteria penilaian menulis puisi, yaitu tema, amanat, pengimajian, diksi, kata konkret, tipografi, dan gaya bahasa. Pada kelas eksperimen terdapat dua siswa yang memperoleh nilai tertinggi yaitu nilai 78 pada tahap pretes.

Sesuai dengan perolehan nilai siswa pada data pretes kelas kontrol yang dikonfirmasikan terhadap nilai KKM Bahasa Indonesia maka dapat dinyatakan bahwa frekuensi dan persentase nilai tingkat kemampuan tes awal kelas kontrol pada 
pembelajaran menulis puisi naratif siswa kelas VIII SMP Negeri 2 Dua Pitue Kabupaten Sidrap, yaitu siswa yang memperoleh nilai $75-81$ sebanyak 9 orang siswa $(33,3 \%)$ dari jumlah sampel, sedangkan siswa yang memperoleh nilai 0 74 sebanyak 18 orang siswa $(66,6 \%)$ dari jumlah sampel.

\section{Tabel 3}

Kategori, Frekuensi, dan Persentase Tes Awal Kelas Eksperimen

\begin{tabular}{|c|c|c|c|}
\hline Interval & Kategori & Frekuensi & $\begin{array}{c}\text { Persentase } \\
(\%)\end{array}$ \\
\hline $86-100$ & $\begin{array}{l}\text { Sangat } \\
\text { baik }\end{array}$ & 0 & 0 \\
\hline $76-85$ & Baik & 3 & 11.1 \\
\hline $56-75$ & Cukup & 19 & 70.3 \\
\hline \multirow[t]{2}{*}{$10-55$} & Kurang & 5 & 18.5 \\
\hline & Jumlah & 27 & 100 \\
\hline
\end{tabular}

tersebut dinyatakan klasifikasi kemampuan menulis teks puisi naratif siswa kelas VIII SMP Negeri 2 Dua Pitue dengan menerapkan model Experiential Learning menunjukkan bahwa hasil pretes siswa kelas eksperimen tidak ada siswa yang memperoleh kategori baik sekali (0\%). Kategori baik diperoleh 3 orang siswa $(11,1 \%)$, kategori cukup diperoleh 19 orang siswa (70,3\%), dan kategori kurang diperoleh 5 orang siswa $(18,5 \%)$.

\section{Tabel 4}

Frekuensi dan Persentase Kriteria Ketuntasan Minimal Hasil Tes Awal Kelas Eksperimen

\begin{tabular}{|c|c|c|c|}
\hline No. & $\begin{array}{c}\text { Perolehan } \\
\text { nilai }\end{array}$ & Frekuensi & Persentase \\
\hline 1 & $\geq 75$ & 3 & 11.1 \\
\hline 2 & $<75$ & 24 & 88.8 \\
\hline 3 & Jumlah & 27 & 100 \\
\hline
\end{tabular}

Sesuai dengan perolehan nilai siswa pada data tes awal kelas eksperimen yang dikonfirmasikan terhadap nilai KKM Bahasa Indonesia, maka dapat dinyatakan bahwa frekuensi dan persentase nilai tingkat kemampuan tes awal kelas eksperimen pada pembelajaran menulis puisi naratif siswa kelas VIII SMP Negeri 2 Dua Pitue
Kabupaten Sidrap, yaitu mendapat nilai 75 -78 sebanyak 3 orang siswa (11.1\%) dan nilai $0-74$ dicapai 24 orang siswa $(88,8 \%)$ dari jumlah sampel.

d. Hasil Analisis Statistik Deskriptif Data Postes Kelas Eksperimen

Pelaksanaan pembelajaran menulis puisi naratif untuk kelas eksperimen pada tahap ini yaitu dengan menerapkan model Experiential Learning. Berdasarkan hasil analisis data postes kelas eksperimen dengan 27 siswa yang dianalisis diperoleh gambaran, yaitu nilai tertinggi, 89 yang diperoleh oleh 1 orang siswa dan nilai terendah yang diperoleh oleh 1 orang siswa adalah 72 .

Berdasarkan perolehan nilai, frekuensi, dan persentase pada tabel maka nilai-nilai tersebut dideskripsikan berdasarkan kategori nilai pada tabel berikut.

\begin{tabular}{|c|c|c|c|}
\hline No. & Kategori & Frekuensi & Persentase \\
\hline $\begin{array}{c}86- \\
100\end{array}$ & $\begin{array}{c}\text { Sangat } \\
\text { Baik }\end{array}$ & 6 & 25.9 \\
\hline $76-85$ & Baik & 16 & 16.67 \\
\hline $56-67$ & Cukup & 5 & 18.5 \\
\hline $10-55$ & Kurang & 0 & 0 \\
\hline & Jumlah & 27 & 100 \\
\hline
\end{tabular}

Berdasarkan karakteristik nilai tersebut dinyatakan klasifikasi kemampuan menulis puisi naratif siswa kelas VIII SMP Negeri 2 Dua Pitue yang menerapkan model Experiential Learning tersebut dinyatakan bahwa hasil postes kelas eksperimen kategori sangat baik diperoleh 6 orang siswa (22.2\%), kategori baik diperoleh 16 orang siswa (59.2\%), kategori cukup diperoleh 5 orang siswa (18.5), dan pada kategori kurang $(0 \%)$.

\section{Tabel 6}

Frekuensi dan Persentase Kriteria Ketuntasan Minimal Hasil Tes Akhir Kelas Eksperimen

\begin{tabular}{|c|c|c|c|}
\hline No. & $\begin{array}{c}\text { Perolehan } \\
\text { Nilai }\end{array}$ & Frekuensi & Persentase \\
\hline 1. & $\geq 75$ & 24 & 88.8 \\
\hline
\end{tabular}




\begin{tabular}{|c|c|c|c|}
\hline 2. & $<75$ & 3 & 11.1 \\
\hline & Jumlah & 27 & 100 \\
\hline
\end{tabular}

Sesuai dengan perolehan nilai siswa pada data postes kelas eksperimen yang dikonfirmasikan nilai KKM Bahasa Indonesia maka diperoleh data dapat dinyatakan bahwa frekuensi dan persentase nilai postes menulis puisi naratif pada kelas eksperimen, yaitu mendapat nilai $75-89$ dicapai sebanyak 24 orang siswa $(88,8 \%)$ dan nilai $0-74$ dicapai 3 orang siswa $(11,1 \%)$. Dengan demikian, dapat dikatakan bahwa hasil postes pada kelas eksperimen sudah memadai karena apabila dikonfirmasikan dengan nilai KKM sekolah pada mata pelajaran bahasa Indonesia, yaitu siswa dikatakan mampu secara individu apabila siswa memperoleh nilai 75-100, dan siswa dikatakan mampu secara klasikal apabila jumlah siswa yang memeroleh nilai 75-100 mencapai 85\%. Berdasarkan analisis tersebut dapat dinyatakan bahwa metode Experiential Learning efektif digunakan dalam pembelajaran menulis puisi naratif siswa kelas VIII.2 SMP Negeri 2 Dua Pitue Kabupaten Sidrap.

\section{Deskripsi Analisis Keefektifan Model Experiential Learning dalam Pembelajaran Menulis Puisi Naratif Siswa Kelas VIII SMP Negeri 2 Dua Pitue Kabupaten Sidrap}

\section{a. Uji Normalitas}

Windows dengan taraf signifikansi 0,05 . Setelah dilakukan pengolahan data, tampilan output uji normalitas data kelas eksperimen untuk kelas VIII.2 sebagai kelas eksperimen. Pengujian normalitas data dilakukan terhadap data hasil belajar pada kelas VIII.2 dan kelas VIII.3. Uji tersebut dilakukan dengan uji $t$ menggunakan program SPSS 20 for.

\section{b. Uji Homogenitas}

Kriteria uji homogenitas adalah jika nilai signifikansi > 0,05 maka data dinyatakan homogen dan jika nilai signifikansi $<0,05$ maka data dinyatakan tidak homogen. Uji homogenitas variasi populasi data hasil belajar menulis teks puisi naratif untuk populasi penelitian ini, menggunakan Test of Homogeneity of Variances. Perhitungan homogenitas variasi populasi diperoleh nilai signifikansi $(p)=$ 0,077 artinya signifikansi $(p)>0,05$, maka data dinyatakan homogen.

\section{c. Uji Hipotesis (t)}

Kaidah pengujian hipotesis diterima apabila nilai $\mathrm{t}_{\text {hitung }} \geq \mathrm{t}$ tabel. Berdasarkan hasil analisis data, maka diperoleh nilai $t_{\text {hitung }}$ sebesar 5,603 dan $t_{\text {tabel }}$ sebesar 5,60356 (Lampiran VIII). Oleh karena nilai $\mathrm{t}$ hitung $\geq \mathrm{t}$ tabel maka hipotesis diterima sehingga ada perbedaan yang signifikan antara kelas yang menggunakan media film dengan menggunakan pengajaran konvensional. Dengan demikian, model pembelajaran Experiential Learning efektif diterapkan dalam pembelajaran menulis teks puisi naratif siswa kelas VIII SMP Negeri 2 Dua Pitue Kabupaten Sidrap.

Kemampuan Menulis Puisi Naratif Siswa Kelas VIII SMP Negeri 2 (Dua) Pitue dengan Menggunakan Model Experiential Learning

Fenomena menunjukkan dalam pembelajaran menulis puisi naratif bagi siswa kelas kontrol, yaitu kemampuan dalam menulis puisi naratif yang hanya menggunakan pengajaran konvensional ternyata tidak sesuai dengan hasil yang didapatkan kelas eksperimen.

Kreativitas siswa dalam menulis puisi naratif belum maksimal. Masih banyak siswa yang tidak memperhatikan tema, amanat, pengimajian, diksi, kata konkret, tipografi, dan gaya bahasa. Hal ini disebabkan kurangnya perhatian guru terhadap cara belajar siswa.

Berdasarkan hasil pengamatan penulis ditemukan hal yang berpengaruh pada rendahnya kemampuan menulis puisi naratif, yaitu (1) pemahaman siswa terhadap menulis puisi naratif masih kurang; (2) guru kurang mengarahkan siswa dalam belajar; 
(3) banyak siswa yang melakukan kegiatan lain saat belajar.

Fenomena yang dialami oleh siswa dalam menulis puisi naratif tersebut berdampak pada evaluasi hasil belajar. Berdasarkan delapan aspek penilaian yaitu memperhatikan tema, amanat, pengimajian, diksi, kata konkret, tipografi, dan gaya bahasa. Hal tersebut disebabkan oleh siswa mengungkapkan puisi naratif berdasarkan pengalaman sendiri. Namun, kemampuan siswa dalam menentukan tema, amanat, pengimajian, diksi, kata konkret, tipografi, dan gaya bahasa. Selain itu, kurangnya kerja sama antara guru dengan siswa sehingga masih banyak siswa yang melakukan aktivitas lain selama proses pembelajaran berlangsung. Dengan demikian, dapat diketahui bahwa frekuensi dan persentase kemampuan siswa menulis puisi narati, yaitu yang memperoleh nilai 75 ke atas sehingga dapat dinyatakan bahwa kemampuan menulis puisi naratif kelas kontrol (tanpa menerapkan model Experiential learning) belum memadai.

Berbeda dengan fenomena yang terjadi dalam pembelajaran menulis puisi naratif siswa kelas VIII SMP Negeri 2 Dua Pitue menerapkan model Experiential Learning. Tampak semua siswa menjadi aktif dalam proses pembelajaran menulis puisi naratif, siswa tampak lebih mengembangkan kreativitasnya. Berdasarkan delapan aspek penilaian yaitu tema, amanat, pengimajian, diksi, kata konkret, tipografi, dan gaya bahasa, diketahui bahwa kemampuan siswa dalam mengungkapkan isi puisi dan pengorganisasian isi puisi dinilai sangat baik dan kreatif yang disebabkan oleh antusias siswa dalam menulis puisi. Model Experiential Learning. Selain itu, adanya kerja sama antara guru dan siswa dalam mendiskusikan langkah-langkah menulis puisi naratif yang baik dan benar turut mengembangkan kreativitas siswa dalam menulis puisi naratif.

Melalui pembelajaran menulis puisi naratif siswa kelas VIII SMP Negeri 2 (Dua) Pitue dengan menggunakan model
Experiential Learning membantu siswa menyelesaikan masalah belajar yang dihadapi. Hal ini dinyatakan karena semua permasalahan pembelajaran dilakukan dengan lebih menarik dan menyenangkan bagi siswa saat pembelajaran berlangsung.

Berdasarkan uraian tersebut dapat disimpulkan bahwa model Experiential Learning tepat digunakan. Hal tersebut berdampak positif pada nilai yang diperoleh siswa dalam menulis puisi naratif dapat dinyatakan bahwa tingkat kemampuan menulis puisi naratif siswa kelas VIII SMP Negeri 2 (Dua) Pitue dikategorikan baik. Demikian halnya dengan ketuntasan belajar rata-rata mencapai kriteria ketuntasan kemampuan menulis puisi siswa kelas VIII SMP Negeri 2 (Dua) Pitue dengan menerapkan model Experiential Learning. Hal ini dibuktikan dari nilai yang diperoleh siswa sampel yang memperoleh nilai $75 \mathrm{ke}$ atas mencapai kriteria tingkat kemampuan siswa sampel yaitu $75 \%$.

Pendapat ahli mengenai keefektifan model Experiential Learning dibuktikan berdasarkan fenomena yang terjadi selama proses pembelajaran menulis puisi naratif siswa kelas VIII SMP Negeri 2 Dua Pitue bahwa kemampuan siswa dalam menulis puisi naratif dinilai sangat baik dan kreatif yang disebabkan oleh antusias siswa dalam menulis puisi naratif. Keantusiasan siswa dalam menulis puisi naratif disebabkan oleh isi dalam puisi naratif menceritakan pengalaman yang mengesankan yang mereka pernah alami. Tema liburan dan peristiwa bersama orang-orang tercinta menjadi semangat tersendiri bagi siswa dalam menulis. Selain itu, adanya kerja sama antara guru dan siswa dalam mendiskusikan langkah-langkah menulis puisi naratif yang baik. Berdasarkan hasil analisis data tes keterampilan menulis puisi naratif, disimpulkan bahwa model Experiential Learning dapat diterapkan.

Keefektifan penggunaan model Experiential Learning juga dinyatakan berdasarkan hasil penelitian yang menunjukkan bahwa kemampuan menulis puisi naratif siswa berada pada kategori 
kemampuan sangat baik. Pernyataan tersebut didukung dan diperkuat berdasarkan hasil perhitungan tes. Hasil kemampuan kelas eksperimen menunjukkan bahwa nilai $t$ hitung $>$ nilai $t$ tabel. Hal ini menunjukkan bahwa hipotesis penelitian yang diajukan dapat diterima.

\section{PENUTUP}

Berdasarkan hasil analisis dan pembahasan dapat disimpulkan tiga hal berikut ini.

Model Experiential Learning efektif digunakan dalam pembelajaran menulis puisi naratif siswa kelas VIII SMP Negeri 2 Dua Pitue Kabupaten Sidrap. Hal ini dibuktikan oleh banyaknya siswa yang mampu menulis puisi naratif, yaitu sebesar $88.7 \%$.

$$
\text { Tanpa menggunakan model }
$$

Experiential Learning tidak efektif dalam pembelajaran menulis puisi naratif siswa kelas VIII SMP Negeri 2 Dua Pitue Kabupaten Sidrap. Hal tersebut dibuktikan oleh kurangnya siswa yang mampu menulis puisi naratif, yaitu hanya sebesar $33,3 \%$. Ada perbedaan yang signifikan antara keefektifan penggunaan model Experiential Learning dengan tanpa menggunakan model Experiential Learning dalam pembelajaran menulis puisi naratif siswa kelas VIII SMP Negeri 2 Dua Pitue Kabupaten Sidrap. Hal ini dibuktikan oleh hasil analisis uji t jenis Independent Samples Test yang menunjukkan thitung $\geq$ ttabel yaitu 5,603 $\geq$ 5,60536. Ini berarti secara signifikan $\mathrm{HO}$ ditolak dan $\mathrm{H} 1$ diterima sehingga ada perbedaan keefektifan model Experiential Learning dengan tanpa model Experiential Learning dalam pembelajaran menulis puisi naratif siswa kelas VIII SMP Negeri 2 Dua Pitue Kabupaten Sidrap. Berdasarkan analisis statistik deskriptif, model Experiential Learning lebih efektif digunakan dalam menulis puisi naratif dibandingkan dengan tanpa model Experiential Learning. Siswa yang mampu menulis puisi naratif setelah menggunakan model Experiential Learning yaitu sebanyak $88,8 \%$, sedangkan siswa yang mampu menulis puisi naratif tanpa menggunakan model Experiential Learning $33,3 \%$.

\section{DAFTAR PUSTAKA}

Ahmadi, Nurdin. 1990. Dasar-Dasar Kompetensi Bahasa Indonesia. Malang: YE.

Aisyah, A. 2013. "Penerapan Teknik Mind Maping dalam Peningkatan

Kemampuan Menulis Puisi Kreatif Siswa Kelas XI SMA Ummul Muknminim Makassar". Tesis. Tidak Diterbitkan. Jurusan Pendidikan Bahasa dan Sastra Indonesia.

Alwasilah, A. Chaedar dkk. 2008. Pokoknya Menulis. Bandung: Kiblat Buku Utama.

Ambo Enre, Fachruddin. 1994. DasarDasar Keterampilan Menulis. Ujung Pandang.

Aminuddin. 2009. Pengantar Apresiasi Karya Sastra. Bandung: Sinar Baru.

A Pribadi, Benny. 2011. Model Desain Sistem Pembelajaran. Jakarta: Dian Rakyat.

Arends, S. I. 2004. Learnin $g$ to Teach. New York: Hill Companies.

Dalman. 2012. Keterampilan Menulis. Jakarta: Raja Grafindo Persada.

Departemen Pendidikan Nasional. 2005. Kamus Besar Bahasa Indonesia Edisi Ketiga. Jakarta: Balai Pustaka

Dola Abdullah. 2014. Dasar-Dasar Teori Sastra Indonesia. Makassar: Camar Dola.

Endah. 2012. Membaca Sastra dengan Ancangan Literasi Kritis. Jakarta: Bumi Aksara

Hamdani. 2011. Strategi Belajar Mengajar. Bandung: Pustaka Setia

Hamalik, Oemar. 2007. Kurikulum dan Pembelajaran. Jakarta: Bumi Aksara.

Kaharuddin, Nurjayanti. 2012. "Keefektifan Metode Karya Wisata (Field Trip) pada Pembelajaran Menulis Puisi Siswa Kelas X SMA Negeri 2 Makassar'. Tesis. Tidak Diterbitkan. Makassar: Jurusan Pendidikan Bahasa Indonesia Program Pascasarjana UNM. 
Kurniawan, Heru dan Sutardi. 2012. Penulisan Sastra Kreatif. Yogyakarta: Graha Ilmu

Kosasih. 2012. Dasar-dasar Keterampilan Menulis. Bandung: Yrama Widya.

Nurgiyantoro, Burhan. 1995. Penilaian dan Pengajaran Bahasa dan Sastra. Yogyakarta: PBFE.

Peraturan Menteri Pendidikan dan Kebudayaan No. 50 Tahun 2015 tentang PUBI (Pedoman Umum Ejaan Bahasa Indonesia).

Pradopo, Rahmat Djoko. 2010. Pengkajian Puisi. Yogyakarta: Gajah Mada University Press.

......... 2012. Pengkajian Puisi.
Yogyakarta: University Press.

Program Pascasarjan Universitas Negeri Makassar. 2012. Pedoman Penulisan Tesis dan Disertasi. Makassar: Badan Penerbit UNM.

Riffaterre, Michel. 1978. Semiotics of poetry. Bloomington: Indiana University Press.

Rantumanan, T. G. 2004. Belajar dan Pembelajaran. Edisi kedua. Ambon: Unesa University Press 2004.
Iriani, Rosary. 2015. "Peningkatan Menulis Puisi Melalui Strategi Pengamatan terhadap Lingkungan SMA Ekkitar Siswa Kelas X SMA Negeri Namlea Kabupaten Buru". Tesis. Tidak Diterbitkan. Makassar: Jurusan Pendidikan Bahasa Indonesia Program Pascasarjana UNM.

Salam. 2009. Pendidikan Penulisan Kreatif. Makassar: Badan Penerbit UNM.

Samosir, Tiorida. 2013. Apresiasi Puisi. Bandung: Yrama Widya.

Subana, 2009. Strategi Belajar Mengajar Bahasa Indonesia. Bandung: Pustaka Setia.

Sugandi, A., dkk. 2004. Teori Pembelajaran. Semarang: UPT MKK UNNES.

Sugiyono. 2015. Statistika untuk Penelitian. Bandung: Alfabeta

Waluyo, H J. 1995. Teori dan Apresiasi Puisi. Jakarta: Erlangga.

Wardi. 2012. Undang-Undang Republik Indonesia No. 20 Tahun 2003 Tentang Sistem Pendidikan Nasional. Jogjakarta: Laksana

Wena. 2011. Strategi Pembelajaran Inovatif Kontemporer. Jakarta: Bumi Aksara. 